\title{
PENGARUH INTRADIALYTIC EXERCISE DAN TERAPI MUSIK KLASIK TERHADAP TEKANAN DARAH INTRADIALSIS PADA PASIEN CKD STAGE V YANG MENJALANI HEMODIALISA
}

\author{
Nia Firdianty Dwiatmojo ${ }^{1)}$ Shofa Chasani $^{2)}$ Henni Kusuma ${ }^{3)}$ \\ ${ }^{1)}$ Staf Pengajar STIKES Mataram, Magister Keperawatan Dewasa Jurusan \\ Keperawatan, Fakultas Kedokteran, Universitas Diponegoro. \\ ${ }^{2}$ Dokter rumah sakit Roemani Muhammadiyah Semarang, Staf Pengajar Keperawatan \\ Dewasa Jurusan Keperawatan, Fakultas Kedokteran, Universitas Diponegoro. \\ ${ }^{3)}$ Staf Pengajar Keperawatan Dewasa Jurusan Keperawatan, Fakultas Kedokteran, \\ Universitas Diponegoro.
}

Email :niazinta86@gmail.com

\begin{abstract}
ABSTRAK
Pendahuluan: Hemodialisa merupakan salah satu terapi pengganti ginjal yang umum dilakukan dan menjadi pilihan bagi banyak penderita Chronic Kidney Disease (CKD) stage V. Selama proses hemodialisa pasien mengalami komplikasi. Hipertensi intradialisis merupakan komplikasi yang sering terjadi dan tidak cukup terkontrol. Berbagai hasil penelitian menyimpulkan bahwa terdapat peran hipertensi intradialisis terhadap peningkatan morbiditas dan mortalitas pasien CKD yang menjalani hemodialisa rutin. Oleh karena itu, dibutuhkan suatu penanganan untuk mengontrol tekanan darah intradialisis. Intradialytic exercise dan terapi musik klasik merupakan intervensi pilihan dan aman dilakukan untuk menurunkan systolic blood pressure (SBP) sehingga dapat menurunkan angka kejadian hipertensi intradialisis. Tujuan: Mengetahui pengaruh intradialytic exercise dan terapi musik klasik terhadap tekanan darah intradialsis pada pasien yang menjalani hemodialisa. Metode: Desain penelitian ini adalah quasi-experiment. Pengambilan sampel dilakukan menggunakan purposive sampling, yang melibatkan 18 orang di kelompok intervensi dan 18 orang di kelompok kontrol. Data dianalisa menggunakan uji Wilcoxon dan Mann-Whitney. Hasil: Hasil penelitian menunjukkan rata-rata peningkatan SBP pada kelompok kontrol $175 \mathrm{mmHg}$, sedangkan pada kelompok intervensi terjadi penururnan SBP rata-rata $166 \mathrm{mmHg}$. Hasil uji Mann-Whitney diperoleh nilai $\mathrm{p}=0.005$, yang berarti bahwa ada perbedaan rata-rata penurunan SBP yang signifikan antara kelompok intervensi dan kelompok kontrol Kesimpulan : Penelitian ini membuktikan bahwa intervensi intradialytic exercise dan terapi musik klasik berpengaruh secara signifikan terhadap penurunan SBP pada pasien CKD stage $\mathrm{V}$ yang menjalani hemodialisa. Penggabungan intervensi ini aplikatif dan efektif untuk menurunkan tekanan darah sehingga dapat mencegah kejadian hipertensi intradalitik, dan merupakan intervensi yang mudah dan murah untuk dilakukan. Saran: Intradialytic exercise dan terapi musik klasik dapat menjadi alternative intervensi keperawatan bagi pasien hemodialisa untuk mencegah hipertensi intradialitik.
\end{abstract}

Kata Kunci : CKD, Hemodialisa, Hipertensi intradialisis, Intradialytic exercise, Terapi musik klasik

\section{PENDAHULUAN}

Hipertensi Intradialisis (HID) cukup terkontrol pada pasien hemodialisa merupakan masalah utama dan tidak (HD), $70 \%$ pasien HD mengalami 
hipertensi intradialisis ${ }^{1}$. HID berpotensi mencetuskan sakit kepala, meningkatkan ketidaknyamanan dan meningkatkan resiko penyakit cardiovaskuler ${ }^{2}$. Berbagai hasil penelitian menyimpulkan bahwa terdapat peran hipertensi intradialisis terhadap peningkatan morbiditas dan mortalitas pasien yang menjalani hemodialisis rutin ${ }^{3}$.

Ketika terjadi HID saat proses hemodialisis, penanganan yang sering dilakukan adalah dengan menurunkan Quick of Blood (QB) dan pemberian obat farmakologis seperti obat-obatan diuretika atau pemberian beta bloker. Penanganan ini menimbulkan efek samping yaitu penurunan adekuasi HD, menjadikan tubuh tidak stabil/fit, kelemahan otot, kejang-kejang dan obat ini mampu menghambat kerja noradrenalin dan adrenalin yang mengakibatkan keadaan pasien memburuk dan menurunkan derajat kesehatan pasien ${ }^{4,5}$.

Pentalaksanaan nonfarmakologis yang telah terbukti dan bermanfaat dalam pengendalian hipertensi intradialisis yaitu intradialytic exercise dan teknik relaksasi seperti terapi musik. Penatalaksanaan non farmakologis ini dapat membuat tubuh menjadi lebih stabil/fit, lebih berenergi dan membuat tidur menjadi lebih baik, sehingga dapat mengurangi kebutuhan penggunaan obat antihipertensi ${ }^{6,7}$.

Intradialytic exercise dan terapi musik klasik dapat meningkatkan pengontrolan tekanan darah pada pasien yang mengalami hipertensi, dan menurunkan resiko kematian akibat penyakit ganguan kardiovaskuler ${ }^{8}$. Dari perspektif fisiologi, pasien HD yang diberikan intradilytic exercise akan mengalami kondisi dimana cairan dalam tubuh dapat dikeluarkan lebih banyak yang mengakibatkan sebagian besar dari urea dan racun keluar dari jaringan ke kompartemen vaskular untuk dihapus berikutnya ke mesin dialyser 9. Sedangkan Musik dapat menurunkan stimulus system syaraf simpatis yang diikuti dengan penurunan aktivitas adrenalin dan ketegangan neuromuskuler, dan dapat menstimulasi tubuh untuk memproduksi molekul nitric oxide (NO) yang bekerja pada tonus pembuluh darah yang dapat menurunkan tekanan darah ${ }^{7}$

\section{METODE}

Jenis penelitian yang dilakukan adalah quasi experiment dengan rancangan pretest-posttest with control group design. Penelitian dilaksanakan di RSUD Provinsi NTB dengan kriteria inklusi: a) menjalani hemodialisa secara rutin, b) pasien berumur 15-64 tahun, c) sudah menjalani HD reguler minimal 3 bulan, d) diijinkan oleh dokter untuk melakukan latihan fisik selama HD, e) bersedia menjadi responden, f) bersedia mendengarkan musik klasik, g) pasien dengan terapi obat antihipertensi sejenis, h) IDWG $\leq 3 \mathrm{~kg}$, i) tekanan darah $\geq$ 140/90 mmHg. Sedangkan kriteria eksklusi: a) mengalami gangguan pada sistem muskuloskeletal, b) mengalami penyakit pada sistem persyarafan/neurologi, c) mengalami perubahan drastis hemodinamik, d) mengalami sesak nafas, e) terpasang akses femoral, f) mengalami gangguan pendengaran.

Besar sampel berdasarkan rumus beda dua mean kelompok independen, dengan $\alpha 5 \%$ dan $\beta 20 \%$, dan perkiraan proporsi drop out $10 \%$, didapatkan jumlah sampel sebanyak 36 responden, yang terbagi menjadi 18 responden kelompok kontrol, dan 18 responden kelompok intervensi.

Intervensi yang dilakukan dengan memberikan Intradialytic exercise pada jam pertama hemodialisa yang dibagi menjadi tiga bagian (pemanasan, inti, dan pendinginan) dengan menggunakan beban tangan (dumble) $1 \mathrm{~kg}$ dan beban kaki (ankle cuff) $1 \mathrm{~kg}$, yang diiringi musik klasik yang mengalir tanpa lirik dengan 60-80 beats menggunakan earphone dan 
mp3 diberikan selama 30 menit, 2 kali seminggu selama 4 minggu 10,11 . Pengumpulan data menggunakan kuesioner yang diambil saat pra intervensi dan post intervensi setelah 4 minggu perlakuan dilakukan, baik pada kelompok intervensi dan kelompok kontrol. Uji homogenitas menggunakan uji chi square untuk melihat tidak ada perbedaan bermakna antara kelompok intervensi dan kelompok kontrol. Uji normalitas data menggunakan Uji Shapiro Wilk karena responden dibawah 50 orang. Hasil uji normalitas data diperoleh $\mathrm{p}<0,05$ yang bermakna data terdistribusi tidak normal sehingga untuk menguji pra dan post pada kelompok intervensi dan kelompok kontrol menggunakan Uji Wilcoxon, dan untuk menguji post intervensi antara kelompok kontrol dan kelompok intervensi menggunakan Uji MannWhitney ${ }^{12}$.

\section{HASIL}

1. Tekanan darah pra dan post intervensi pada kelompok kontrol dan kelompok intervensi

Tabel 4.2 Tekanan darah pra dan post HD selama 8 sesi pada kelompok intervensi di RSUD Provinsi NTB $(\mathrm{n}=18)$

\begin{tabular}{|c|c|c|c|c|}
\hline \multicolumn{2}{|c|}{$\begin{array}{l}\text { Tekanan Darah } \\
\quad(\mathrm{mmHg})\end{array}$} & \multirow{2}{*}{$\begin{array}{c}\text { Pra HD } \\
\text { Mean } \pm \text { SD } \\
(\min -\max )\end{array}$} & \multirow{2}{*}{$\begin{array}{c}\begin{array}{c}\text { Post HD } \\
\text { Mean } \pm \text { SD } \\
(\min -\max )\end{array} \\
182 \pm 11,14 \\
(150-190)\end{array}$} & \multirow{2}{*}{$\begin{array}{c}\mathrm{P} \\
0.000\end{array}$} \\
\hline Sesi 1 & Sistolik & & & \\
\hline & Diastolik & $\begin{array}{l}115 \pm 10,43 \\
(100-130) \\
\end{array}$ & $\begin{array}{l}108 \pm 10,98 \\
(100-130)\end{array}$ & 0.03 \\
\hline \multirow[t]{2}{*}{$\overline{\text { Sesi } 2}$} & Sistolik & $\begin{array}{l}172 \pm 12,48 \\
(150-190)\end{array}$ & $\begin{array}{c}182 \pm 9,42 \\
(160-190)\end{array}$ & 0.000 \\
\hline & Diastolik & $\begin{array}{l}112 \pm 11,27 \\
(100-130)\end{array}$ & $\begin{array}{l}109 \pm 11,09 \\
(100-130)\end{array}$ & 0.37 \\
\hline \multirow[t]{2}{*}{ Sesi 3} & Sistolik & $\begin{array}{l}170 \pm 15,71 \\
(150-190)\end{array}$ & $\begin{array}{c}170 \pm 9,37 \\
(160-190)\end{array}$ & 0.96 \\
\hline & Diastolik & $\begin{array}{c}115 \pm 7,83 \\
(100-130) \\
\end{array}$ & $\begin{array}{l}112 \pm 11,14 \\
(100-130) \\
\end{array}$ & 0.3 \\
\hline \multirow[t]{2}{*}{ Sesi 4} & Sistolik & $\begin{array}{l}165 \pm 15,04 \\
(150-190)\end{array}$ & $\begin{array}{c}169 \pm 9,98 \\
(160-190)\end{array}$ & 0.14 \\
\hline & Diastolik & $\begin{array}{c}115 \pm 7,83 \\
(100-130) \\
\end{array}$ & $\begin{array}{l}113 \pm 10,57 \\
(100-130)\end{array}$ & 0.47 \\
\hline \multirow[t]{2}{*}{ Sesi 5} & Sistolik & $\begin{array}{l}167 \pm 10,74 \\
(150-180)\end{array}$ & $\begin{array}{l}161 \pm 13,23 \\
(150-190)\end{array}$ & 0.04 \\
\hline & Diastolik & $\begin{array}{l}115 \pm 10,98 \\
(100-130) \\
\end{array}$ & $\begin{array}{c}113 \pm 7,66 \\
(100-120) \\
\end{array}$ & 0.69 \\
\hline \multirow[t]{2}{*}{ Sesi 6} & Sistolik & $\begin{array}{l}168 \pm 10,03 \\
(150-180)\end{array}$ & $\begin{array}{l}161 \pm 13,23 \\
(150-190)\end{array}$ & 0.01 \\
\hline & Diastolik & $\begin{array}{l}108 \pm 10,43 \\
(100-130) \\
\end{array}$ & $\begin{array}{c}107 \pm 8,26 \\
(100-120) \\
\end{array}$ & 0.7 \\
\hline
\end{tabular}

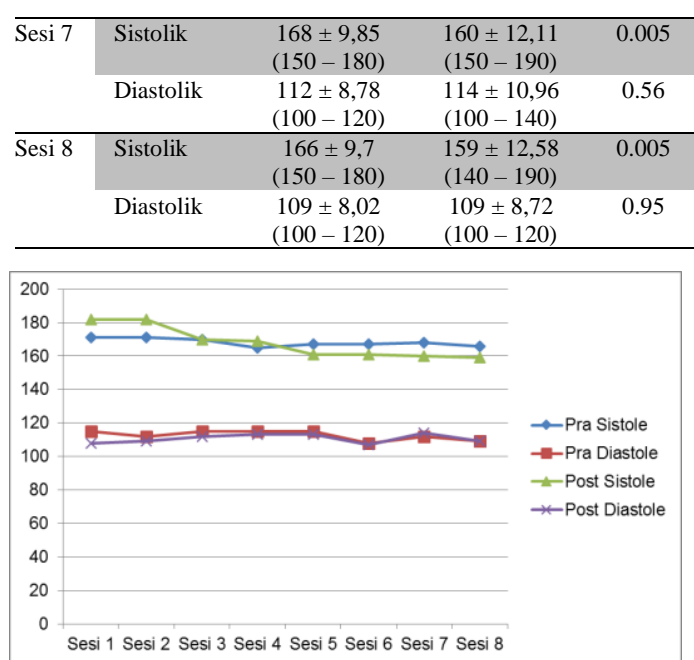

Grafik 4.1 Tekanan darah pra dan post HD selama 8 sesi pada kelompok intervensi

Berdasarkan tabel 4.2 dapat dilihat hasil tekanan darah sistolik pada akhir (sesi 8) pemberian intervensi intradialyic exercise dan terapi musik klasik terjadi penurunan secara signifikan dari pra HD ke post HD ( $\mathrm{p}=$ 0.005) dengan perubahan tekanan darah sistolik post intervensi 159,44 mmHg. Pada awal pemberian intervensi di minggu pertama masih terjadi peningkatan tekanan darah sistolik terjadi dari pra HD ke post HD $(\mathrm{p}=0.000)$ dengan nilai mean yang lebih tinggi pada post HD 182,22 $\mathrm{mmHg}$.

Grafik 4.1 menunjukkan pemberian intervensi intradialyic exercise dan terapi musik klasik memberikan dampak penurunan tekanan darah sistolik secara teratur, hal ini dapat dilihat pada nilai mean tekanan darah sistolik yang semakin menurun dari sesi 1 sampai sesi 8 . Sedangkan pada tekanan darah diastolik tidak terjadi penurunan secara bermakna pada setiap sesinya.

Penurunan tekanan darah mulai stabil terjadi di minggu ketiga (sesi 5 \& sesi 6) dan keempat (sesi $7 \&$ sesi 8). Pada minggu ketiga terjadi penurunan tekanan darah sistolik secara bermakna dapat dilihat pada sesi $5 \mathrm{p}=0.04$ dan sesi $6 \mathrm{p}=0.04$. Pada minggu keempat 
terjadi penurunan tekanan darah secara bermakna dibandingkan dengan minggu ketiga yang ditunjukkan pada sesi $7 \mathrm{p}=0.01$ dan sesi $8 \mathrm{p}=0.005$.

Hal ini menunjukkan bahwa pada kelompok intervensi yang diberikan perlakuan intradialyic exercise dan terapi musik klasik 2 kali seminggu selama 4 minggu secara berturut-turut memberikan dampak secara signifikan penurunan tekanan darah sistolik secara teratur sehingga dapat menghindari kejadian hipertensi intradialitik.

Tabel 4.3 Tekanan darah pra dan post

HD selama 8 sesi pada kelompok kontrol di RSUD Provinsi NTB ( $n=18$

\begin{tabular}{|c|c|c|c|c|c|}
\hline \multicolumn{2}{|c|}{$\begin{array}{l}\text { Tekanan Darah } \\
\quad(\mathrm{mmHg})\end{array}$} & \multirow{2}{*}{$\begin{array}{c}\text { Pra HD } \\
\begin{array}{c}\text { Mean } \pm \text { SD } \\
(\min -\max )\end{array} \\
170 \pm 11,09 \\
(150-190)\end{array}$} & \multicolumn{2}{|c|}{$\begin{array}{c}\text { Post HD } \\
\text { Mean } \pm \text { SD } \\
(\min -\max )\end{array}$} & \multirow{2}{*}{$\begin{array}{c}\mathrm{P} \\
0.000\end{array}$} \\
\hline \multirow[t]{2}{*}{ Sesi 1} & Sistolik & & $\begin{array}{l}184= \\
(170\end{array}$ & $\begin{array}{r}10,96 \\
-200)\end{array}$ & \\
\hline & Diastolik & $\begin{array}{c}113 \pm 9,7 \\
(100-130)\end{array}$ & $\begin{array}{l}116 \\
(100\end{array}$ & $\begin{array}{l}6,07 \\
-120)\end{array}$ & 0.37 \\
\hline \multirow[t]{2}{*}{ Sesi 2} & Sistolik & $\begin{array}{c}169 \pm 7,58 \\
(160-180)\end{array}$ & $\begin{array}{c}182 \\
(170\end{array}$ & $\begin{array}{r}6,46 \\
-190)\end{array}$ & 0.000 \\
\hline & Diastolik & $\begin{array}{c}112,77 \pm 8,26 \\
(100-120)\end{array}$ & $\begin{array}{r}116 \\
6 \\
(100\end{array}$ & $\begin{array}{l}11 \pm \\
97 \\
-120)\end{array}$ & 0.29 \\
\hline \multirow[t]{2}{*}{ Sesi 3} & Sistolik & $\begin{array}{c}166 \pm 6,97 \\
(160-180)\end{array}$ & $\begin{array}{l}178= \\
(160\end{array}$ & $\begin{array}{r}12,15 \\
-190)\end{array}$ & 0.002 \\
\hline & Diastolik & $\begin{array}{c}111,66 \pm 9,85 \\
(100-130)\end{array}$ & $\begin{array}{r}116 \\
8 \\
(100\end{array}$ & $\begin{array}{l}11 \pm \\
49 \\
-130)\end{array}$ & 0.18 \\
\hline \multirow[t]{2}{*}{$\overline{\text { Sesi } 4}$} & Sistolik & $\begin{array}{l}175 \pm 10,98 \\
(160-190)\end{array}$ & $\begin{array}{l}179= \\
(150\end{array}$ & $\begin{array}{r}19,67 \\
-200)\end{array}$ & 0.12 \\
\hline & Diastolik & $\begin{array}{c}114 \pm 7,83 \\
(100-130)\end{array}$ & $\begin{array}{l}119 \\
(110\end{array}$ & $\begin{array}{c}8,02 \\
-140)\end{array}$ & 0.02 \\
\hline \multirow[t]{2}{*}{ Sesi 5} & Sistolik & $\begin{array}{c}170 \pm 4,85 \\
(160-180)\end{array}$ & $\begin{array}{l}180= \\
(160\end{array}$ & $\begin{array}{r}14,14 \\
-200)\end{array}$ & 0.008 \\
\hline & Diastolik & $\begin{array}{c}116,66 \pm 6,85 \\
(100-120)\end{array}$ & $\begin{array}{l}115 \\
(100\end{array}$ & $\begin{array}{l}7,07 \\
-120)\end{array}$ & 0.45 \\
\hline \multirow[t]{2}{*}{$\overline{\text { Sesi } 6}$} & Sistolik & $\begin{array}{c}166 \pm 5,94 \\
(160-180)\end{array}$ & $\begin{array}{l}174= \\
(150\end{array}$ & $\begin{array}{r}11,99 \\
-190)\end{array}$ & 0.01 \\
\hline & Diastolik & $\begin{array}{c}112 \pm 8,78 \\
(100-120)\end{array}$ & $\begin{array}{l}117 \\
(100\end{array}$ & $\begin{array}{r}5,74 \\
-120) \\
\end{array}$ & 0.08 \\
\hline \multirow[t]{2}{*}{ Sesi 7} & Sistolik & $\begin{array}{c}166 \pm 6,97 \\
(160-180)\end{array}$ & $\begin{array}{l}173= \\
(150\end{array}$ & $\begin{array}{r}13,71 \\
-190)\end{array}$ & 0.02 \\
\hline & Diastolik & $\begin{array}{l}113 \pm 10,28 \\
(100-130)\end{array}$ & $\begin{array}{l}116 \\
(100\end{array}$ & $\begin{array}{r}8,49 \\
-130) \\
\end{array}$ & 0.43 \\
\hline \multirow[t]{2}{*}{ Sesi 8} & Sistolik & $\begin{array}{l}175 \pm 10,98 \\
(160-190)\end{array}$ & $\begin{array}{l}178= \\
(150\end{array}$ & $\begin{array}{r}19,67 \\
-200)\end{array}$ & 0.12 \\
\hline & Diastolik & $\begin{array}{c}115 \pm 8,57 \\
(100-130)\end{array}$ & $\begin{array}{r}120 \\
(110 \\
\end{array}$ & $\begin{array}{r}7,66 \\
-140) \\
\end{array}$ & 0.07 \\
\hline \multicolumn{6}{|l|}{200} \\
\hline 180 & \multicolumn{5}{|c|}{$\rightarrow-2$} \\
\hline 140 & \multicolumn{5}{|c|}{ 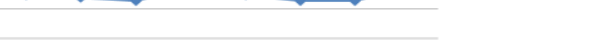 } \\
\hline 120 & \multicolumn{3}{|c|}{ 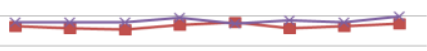 } & \multirow{4}{*}{\multicolumn{2}{|c|}{$\begin{array}{l}\rightarrow \text { Pra Sistole } \\
\rightarrow \text { Pra Diastole } \\
\text {-Post Sistole } \\
\leftarrow \text { Post Diastole }\end{array}$}} \\
\hline 100 & & & & & \\
\hline \multirow{2}{*}{$\begin{array}{l}80 \\
60\end{array}$} & & & & & \\
\hline & & & & & \\
\hline \multicolumn{6}{|l|}{40} \\
\hline \multicolumn{6}{|l|}{20} \\
\hline 0 & Sesi $1 \mathrm{Sesi} 2 \mathrm{Se}$ & si 5 & & & \\
\hline
\end{tabular}

Grafik 4.2 Tekanan darah pra dan post HD selama 8 sesi pada kelompok control
Tabel 4.3 menunjukkan bahwa pada kelompok kontrol yang tidak diberikan intervensi intradialyic exercise dan terapi musik klasik, tekanan darah intradialisis tidak terkontrol dan tetap mengalami peningkatan tekanan darah sistolik pra HD ke post HD dari sesi 1 sampai sesi 8. Peningkatan tekanan darah sistolik terjadi secara signifikan di setiap minggu terutama pada minggu ketiga sesi $5(\mathrm{p}=0.008)$ dan minggu keempat sesi $7(\mathrm{p}=0.02)$ mean SBP post HD. tekanan darah daistolik tidak terjadi peningkatan secara signifikan hampir di setiap sesinya.

Grafik 4.2 menunjukkan bahwa pada kelompok kontrol yang tidak diberikan perlakuan intradialyic exercise dan terapi musik klasik 2 kali seminggu selama 4 minggu secara berturut-turut menunjukkan adanya peningkatan tekanan darah dalam setiap sesi hemodialisa. Hal ini menggambarkan bahwa pada kelompok kontrol kejadian hipertensi intradialitik dapat dialami di setiap sesi hemodialisa.

2. Tekanan darah intradialisis post intervensi antara kelompok kontrol dan kelompok intervensi

Tabel 4.5 Tekanan darah post hemodialisa antara kelompok intervensi dan kelompok kontrol di RSUD Provinsi NTB $(n=36)$

\begin{tabular}{|c|c|c|c|c|c|}
\hline \multicolumn{2}{|c|}{$\begin{array}{l}\text { Tekanan Darah } \\
(\mathrm{mmHg})\end{array}$} & \multicolumn{2}{|c|}{$\begin{array}{l}\text { Kontrol } \\
\text { Mean } \quad \pm \\
\text { SD } \\
(\min -\max )\end{array}$} & $\begin{array}{l}\text { Intervensi } \\
\text { Mean } \pm \mathrm{SD} \\
(\min -\max )\end{array}$ & $\mathrm{P}$ \\
\hline $\begin{array}{l}\text { Sesi } \\
1\end{array}$ & Sistolik & $\begin{array}{l}184 \\
10,96 \\
(170 \\
200)\end{array}$ & \pm & $\begin{array}{l}182 \pm 11,14 \\
(150-190)\end{array}$ & 0.64 \\
\hline & Diastolik & $\begin{array}{l}116 \\
6,07 \\
(100 \\
120)\end{array}$ & \pm & $\begin{array}{l}108 \pm 10,98 \\
(100-130)\end{array}$ & 0.01 \\
\hline $\begin{array}{l}\text { Sesi } \\
2\end{array}$ & Sistolik & $\begin{array}{l}182 \\
6.47 \\
(170 \\
190)\end{array}$ & \pm & $\begin{array}{l}182 \pm 9,42 \\
(160-190)\end{array}$ & 0.7 \\
\hline
\end{tabular}




\begin{tabular}{|c|c|c|c|c|c|}
\hline & Diastolik & $\begin{array}{l}116 \\
6,97 \\
(100 \\
120) \\
\end{array}$ & \pm & $\begin{array}{l}109 \pm 11,09 \\
(100-130)\end{array}$ & 0.03 \\
\hline \multirow[t]{2}{*}{$\begin{array}{l}\text { Sesi } \\
3\end{array}$} & Sistolik & $\begin{array}{l}178 \\
12,15 \\
(160 \\
190)\end{array}$ & \pm & $\begin{array}{r}170 \pm 9,37 \\
(160-190)\end{array}$ & 0.06 \\
\hline & Diastolik & $\begin{array}{l}116 \\
8,49 \\
(100 \\
130)\end{array}$ & $\begin{array}{l} \pm \\
-\end{array}$ & $\begin{array}{l}112 \pm 11,14 \\
(100-130)\end{array}$ & 0.27 \\
\hline \multirow[t]{2}{*}{$\begin{array}{l}\text { Sesi } \\
4\end{array}$} & Sistolik & $\begin{array}{l}179 \\
19,67 \\
(150 \\
200)\end{array}$ & \pm & $\begin{array}{l}169 \pm 9,98 \\
(160-190)\end{array}$ & 0.09 \\
\hline & Diastolik & $\begin{array}{l}119,44 \\
8,02 \\
(110 \\
140) \\
\end{array}$ & \pm & $\begin{array}{l}113,33 \quad \pm \\
10,28 \\
(100-130)\end{array}$ & 0.09 \\
\hline \multirow[t]{2}{*}{$\begin{array}{l}\text { Sesi } \\
5\end{array}$} & Sistolik & $\begin{array}{l}180 \\
14,14 \\
(160 \\
200)\end{array}$ & \pm & $\begin{array}{l}161 \pm 13,23 \\
(150-190)\end{array}$ & 0.001 \\
\hline & Diastolik & $\begin{array}{l}115 \\
7,07 \\
(100 \\
120) \\
\end{array}$ & \pm & $\begin{array}{l}113,33 \quad \pm \\
7,66 \\
(100-120)\end{array}$ & 0.49 \\
\hline \multirow[t]{2}{*}{$\begin{array}{l}\text { Sesi } \\
6\end{array}$} & Sistolik & $\begin{array}{l}174 \\
11,99 \\
(150 \\
190)\end{array}$ & \pm & $\begin{array}{l}161 \pm 13,23 \\
(150190)\end{array}$ & 0.004 \\
\hline & Diastolik & $\begin{array}{l}117 \\
5,74 \\
(100 \\
120) \\
\end{array}$ & $\begin{array}{l} \pm \\
-\end{array}$ & $\begin{array}{l}107 \pm 8,26 \\
(100-120)\end{array}$ & 0.001 \\
\hline \multirow[t]{2}{*}{$\begin{array}{l}\text { Sesi } \\
7\end{array}$} & Sistolik & $\begin{array}{l}173 \\
13,71 \\
(150 \\
190)\end{array}$ & \pm & $\begin{array}{l}160 \pm 12,11 \\
(150-190)\end{array}$ & 0.007 \\
\hline & Diastolik & $\begin{array}{l}116,11 \\
8,49 \\
(100 \\
130) \\
\end{array}$ & \pm & $\begin{array}{l}114,44 \quad \pm \\
10,96 \\
(100-140)\end{array}$ & 0.41 \\
\hline \multirow[t]{2}{*}{$\begin{array}{l}\text { Sesi } \\
8\end{array}$} & Sistolik & $\begin{array}{l}179 \\
19,67 \\
(150 \\
200)\end{array}$ & \pm & $\begin{array}{l}159 \pm 12,58 \\
(140-190)\end{array}$ & 0.005 \\
\hline & Diastolik & $\begin{array}{l}120 \\
7,66 \\
(110 \\
140) \\
\end{array}$ & \pm & $\begin{array}{l}109 \pm 8,72 \\
(100-120)\end{array}$ & 0.001 \\
\hline
\end{tabular}

Hasil uji statisik pada tabel 4.5 menunjukkan bahwa pada kelompok intervensi terjadi penurunan tekanan darah dari sesi 1 sampai sesi 8, hal ini dapat dilihat dari nilai mean tekanan darah sistolik yang terus menurun secara teratur. Sedangkan pada kelompok kontrol tekanan darah sistolik tidak terkontrol dan tetap terjadi peningkatan tekanan darah sistolik di setiap sesinya.

Hasil uji Mann Whitney diketahui bahwa ada perbedaan tekanan darah sistolik yang signifikan antara kelompok intervensi dan kelompok kontrol yang dimulai pada minggu ketiga (sesi $5 \mathrm{p}=0.001$ dan sesi 6 $\mathrm{p}=0.004$ ), dan minggu keempat (sesi 7 $\mathrm{p}=0.007$ dan sesi $8 \mathrm{p}=0.005$ )

Hal menunjukkan bahwa pemberian intervensi intradialyic exercise dan terapi musik klasik 2 kali seminggu secara berturut-turut dapat menurunkan tekanan darah sistolik secara signifikan pada minggu ketiga dan minggu keempat sehingga dapat menghindari kejadian hipertensi intradialitik.

\section{PEMBAHASAN}

Berdasarkan telaah literatur menyatakan bahwa dari perspektif fisiologi pada pasien HD yang diberikan intradilytic exercise akan mengalami kondisi dimana cairan dalam tubuh dapat dikeluarkan lebih banyak selain dari tarikan mesin HD melalui pernafasan dan penguapan kulit. Intradialytic exercise mengakibatkan melebarnya luas permukaan kapiler di otot, pembuluh darah menjadi melebar sehingga dapat menarik cairan dari ekstravaskuler dengan dibantu otot-otot yang berkontraksi dan meningkatkan aliran darah otot yang mengakibatkan sebagian besar dari urea dan racun keluar dari jaringan ke kompartemen vaskular untuk dihapus berikutnya ke mesin dialyser ${ }^{6}$.

Intradialytic exercise merupakan latihan yang dilakukan pada saat menjalani hemodialisis, merupakan pilihan yang aplikatif dan layak dilakukan pada pasien HD, pasien berada dalam pengawasan dokter dan perawat karena dilakukan saat proses HD, dan dapat dilakukan saat HD berlangsung sehingga tidak membutuhkan tambahan waktu untuk melakukannya di saat yang sama. Intradialytic exercise dapat menurunkan tekanan darah intradialisis, dan efektif dilakukan pada 1-2 jam pertama pertama 
hemodialisis minimal dilakukan selama 30 menit tiga kali perminggu selama 8 minggu.

Musik memiliki kekuatan untuk mengobati penyakit dan meningkatkan kemampuan pikiran seseorang. Hal ini disebabkan musik memiliki beberapa kelebihan, yaitu karena musik bersifat nyaman, menenangkan, membuat rileks, berstruktur, dan universal. Musik dapat menurunkan stimulus system syaraf simpatis yang diikuti dengan penurunan aktivitas adrenalin dan ketegangan neuromuskuler. Penurunan aktivitas tersebut dapat diukur dengan indikator menurunnya hearth rate, respiratory rate dan tekanan darah. Musik ternyata mampu mengaktivasi system limbik yang berhubungan dengan emosi, saat system limbik teraktivasi maka individu tersebut menjadi rileks. Selain itu pula alunan musik juga dapat menstimulasi tubuh untuk memproduksi molekul nitric oxide (NO). Molekul ini bekerja pada tonus pembuluh darah yang dapat menurunkan tekanan darah. ${ }^{7}$

Musik yang direkomendasikan sebagai intervensi adalah musik yang mengalir tanpa lirik dengan 60-80 beats per minute yang terdiri dari tones yang rendah dengan strings, dan dengan minimal brass percussions. Tingkat volume yang direkomendasikan adalah 60 decibels $(\mathrm{dB}){ }^{7}$

Intradialytic exercise dan terapi musik klasik merupakan intervensi pilihan yang aplikatif dan aman dalam penurunan tekanan darah intradialisis, karena pasien berada dalam pengawasan dokter dan perawat, mudah dan murah untuk dilakukan. ${ }^{6,7}$. Kedua intervensi yaitu intradialytic exercise dan terapi musik klasik ini telah terbukti mampu menurunkan tekanan darah intradialisis, sehingga dengan penggabungan intervensi ini dapat digunakan untuk pengendalian terjadinya hipertensi intradialisis.

\section{KESIMPULAN}

Hipertensi intradialisis merupakan komplikasi hemodialisa yang sering terjadi dan tidak cukup terkontrol. Hipertensi intradialisis memiliki peran dalam meningkatkan morbiditas dan mortalitas pada pasien CKD yang menjalani hemodialisa rutin. Berdasarkan telaah dari beberapa hasil publikasi yang telah dilakukan dinyatakan bahwa intradialytic exercise dan terapi musik klasik merupakan intervensi pilihan yang aplikatif dan aman dalam penurunan tekanan darah intradialisis, karena pasien berada dalam pengawasan dokter dan perawat, mudah dan murah untuk dilakukan. 


\section{DAFTAR PUSTAKA}

1. Armiyati Y. Hipotensi dan hipertensi intradialisis pada pasien Chronic Kidney Disease ( CKD ) saat menjalani hemodialisis. Semin hasilhasil penelitian-LPPM UNIMUS 2012; 126-35.

2. Morse SA, Dang A, Thakur V, et al. Hypertension in chronic dialysis patients: pathophysiology, monitoring, and treatment. Am J Med Sci 2003; 325: 194-201.

3. Gallen OS. Intradialytic complications. 40th Annu Meet Swiss Soc Nephrol 2008; 138: 47-48.

4. Ayu IG, Astuti P. Hubungan antara QB dengan adekuasi hemodialisis pada pasien yang menjalani terapi hemodialisis. 2010.

5. Girija K, Radha R. Beneficial Effect of Physical Activity in Hemodialysis Patients. Univers J Eng Sci 2013; 1: 40-44.

6. Sheng K, Zhang P, Chen L, et al. Intradialytic exercise in hemodialysis patients: A systematic review and meta-analysis. Am J Nephrol 2014; 40: 478-90.

7. Carvalho VO. Effect of music therapy on blood pressure of individuals with hypertension: A systematic review and Meta-analysis. Int $J$ Cardiol. Epub ahead of print 2016. DOI: 10.1016/j.ijcard.2016.03.197.

8. Johansen KL. Disease of the Month Exercise in the End-Stage Renal Disease Population. 2007; 18451854.

9. Ouzouni S, Kouidi E, Sioulis A, et al. Effects of intradialytic exercise training on health-related quality of life indices in haemodialysis patients. Epub ahead of print 2009. DOI: 10.1177/0269215508096760.

10. Hidayati W. Mengontrol tekanan darah dengan intradialytic exercise pada pasien yang menjalani hemodialisis
http://eprints.undip.ac.id/46653/1/Pro ceding_SEMILNASKEP_UNDIP_20 15_.pdf\#page=241 (2015).

11. Sarayar C, Blu D, Prof R, et al. Pengaruh musik klasik terhadap penurunan tekanan darah pada pasien pra-hemodilisis di ruang Dahlia BLU RSUP. DR. R. D. Kandaou Manado. ejournal keperawatan (e-Kp) 2013; I: 1.

12. M. Sopiyudin Dahlan. Deskriptif, Bivariat, dan Multivariat Dilengkapi Apliaksi dengan Menggunakan SPSS. Jakarta.: Salemba medika., 2008. 
Pengaruh Intradialytic Exercise dan Terapi Musik Klasik Terhadap Tekanan Darah Intradialsis Pada Pasien CKD Stage V Yang Menjalani Hemodialisa

NiaFirdianti Dwiatmojo

Hubungan Pengetahuan lbu Tentang Toilet TrainingDengan Elaksanaan Toilet TrainingPada AnakToddlerDi Kelurahan KarangPule Kota Mataram Indah Wasliah

Hubungan Status Gizi Dengan Tingkat Perkembangan Balita Wilayah Kerja Puskesmas Pelangan Kabupaten Lombok Barat

Novi Enis Rosuliana

Hubungan Dukungan Keluarga Dengan Motivasi Pasien Pasca Stroke Dalam Melakukan Latihan Rehabilitasi Medik Di Poliklinik Rsud Provinsi NTB Tahun 2019

Ernawati

Pengaruh Pemberian Self Hypnosis Terhadap Pemenuhan Kebutuhan Tidur Pada Lansia Di Lingkungan Gedur Baru Mataram

I Made Eka Santosa

Peran Kader Kesehatan Dalam Meningkatkan Kunjungan Ibu Balita Ke Posyandu Di Wilayah Kerja Puskesmas Tanjung Karang Kota Mataram

Sukardin

PengaruhSenam Lansia Terhadap Perubahan Nyeri Sendi Pada Lansia Di Balai Sosial Lanjut Usia (Bslu)Mandalika Mataram

FebriatiAstuti

Pengaruh Penerapan Family Centered Care Terhadap Pelaksanaan Personal Hygiene (Memandikan)

Ageng Abdi Putra

Perbedaan Ketepatan Antara Rumus Johnson Toshach, Rumus Modifikasi Johnson Menurut Syahrir, Rumus Niswander Dan Rumus Sml Dalam Menaksir Berat Badan Lahir DiRuang Bersalin Rsud Kota Mataram

Dina Fithriana

Pemenuhan Kebutuhan Seksual Lansia Dengan Mekanisme Koping Yang Digunakan Lansia Di Desa Pohgading Gubuk Timuq Kabupaten Lombok Timur

Ni Made Sumartyawati

Hubungan Karakteristik Ibu Dengan Sikap IbuHamil Trimester III Dalam Pemilihan Penolong Persalinan Di Wilayah Kerja Puskesmas Pai Kabupaten Bima

Robiatul Adawiyah

Efektivitas Jus Mentimun Terhadap Perubahan Tekanan Darah Pada Lansia Penderita Hipertensi Di Lingkungan Dasan Sari Wilayah Kerja Puskesmas Pejeruk

Eva Marvia

Pengaruh Masase Teknik Effleurage Terhadap Lansia Penderita Hipertensi Di Lingkungan Batu Ringgit Selatan Kelurahan Tanjung Karang Kota Mataram

Baiq Nova Aprilia Azamti

Analisis Usaha Kesehatan Masyarakat Berdasarkan Manajemen Umum Yang Berkwalitas Di Puskesmas

Mustim Tasim

Pengaruh Peer ReviewTentang Kesehatan Reproduksi Terhadap Sikap Remaja Tentang Seksual Pranikah DiKelas X. MIA I Dan XI. BSMAN 9 Mataram 